\title{
Continental Trace Fossils in the Semnan Area (Northern Iran)
}

\author{
Mousa Bagheri ${ }^{1 *}$, Sadat Feiznia ${ }^{2}$, Mehran Arian ${ }^{1}$, Rahim Shabanian $^{3}$, Rahim Mahari $^{4}$ \\ ${ }^{1}$ Geology Department, Faculty of Science, Science and Research Branch, Islamic Azad University, Tehran, Iran \\ ${ }^{2}$ Faculty of Natural Resources, University of Tehran, Tehran, Iran \\ ${ }^{3}$ Geology Department, Faculty of Science, Tabriz Branch, Payam Noor University, Tabriz, Iran \\ Geology Department, Faculty of Science, Tabriz Branch, Islamic Azad University, Tabriz, Iran \\ Email: "geo.bagheri@yahoo.com
}

Received October 30, 2012; revised November 30, 2012; accepted December 25, 2012

Copyright (C) 2013 Mousa Bagheri et al. This is an open access article distributed under the Creative Commons Attribution License, which permits unrestricted use, distribution, and reproduction in any medium, provided the original work is properly cited.

\begin{abstract}
Continental ichnology has been taking an ever increasing importance in stratigraphy. In this paper, Continental Trace Fossils in Semnan area have been studied. Semnan Province is one of the 31 provinces which is located in the north of Iran. In the East of Semnan City, Quaternary deposits occupy about 93\% of the surface area, of which the Alluvial represents one of the most important geomorphological features in the area. Nevertheless, the outspread ichnological studies in Semnan City have received lesser attention in Continental Trace Fossils. Based on the systematic ichnology, 6 trace fossils are distinguished, namely Celliforma isp, Coprinisphaera isp, Palaeophycus tubularis, planolithes isp, Tombownichnus plenus, and Skolithos isp. The existence of Rhizoliths along with the tetrapod footprints and the survey of lithofacies all indicate that the trace fossils are related to Coprinisphaera ichnofacies. Based on ichnological and sedimentary facies analysis, the Continental Trace Fossils, in the study area, are located in the flood plain, point bar, and playa environment.
\end{abstract}

Keywords: Continental Ichnology; Coprinisphaera Ichnofacies; Quaternary; Trace Fossils; Semnan

\section{Introduction}

Trace Fossil Analysis is most commonly used to determine the general characteristics of the paleo-depositional setting and to refine our knowledge of sedimentological and chemical parameters. In the last ten years, trace fossils have become a powerful tool in the analysis of continental paleoenvironments [1]. Traces left in the sediment and preserved as trace fossils, represent a record of animal behavior. The size, distribution, and variety of traces observed in a sedimentary unit reflects the salinity, oxygen content, sediment pore-water content, temperature, food availability, sedimentation rate, substrate consistency, turbidity, predation, energy, and subaerial exposure of a locale at the time of deposition [2,3].

In fact, the relationship between environmental conditions and the preserved trace assemblage have shown predictable results in the development of ichnofacies [4,5] and ichnocoenoses.

In recent years, continental ichnology has been taking an ever increasing importance in stratigraphy, basin ana-

${ }^{*}$ Corresponding author. lysis, and paleogeography along with experiencing a rapid development during the last decade. Trace fossils have critical implements to recognize the environmental parameters in nonmarine settings, as they are in marine paleo environments. They provide detailed information about life in the past [6,7]. The aim of the authors in this paper is to interpret the depositional environment of the Semnan Quaternary Sediments based on Ichnofossils and their assemblages.

\section{Study Area}

Semnan Province is one of the 31 provinces of Iran. It is in the north of the country, and its center is Semnan City. Semnan province, as shown in Figure 1, with the 5.6\% of the whole area of Iran is the sixth big province in the country. The center of this province, Semnan, is located at $228 \mathrm{~km}$ away from Tehran and its distance from the international waters of the Persian Gulf and the Caspian Sea, in turn, is 1600 and $200 \mathrm{~km}$. The province is divided into two parts: a mountainous region, and the plains at the foot of the mountains. It is built from the north 


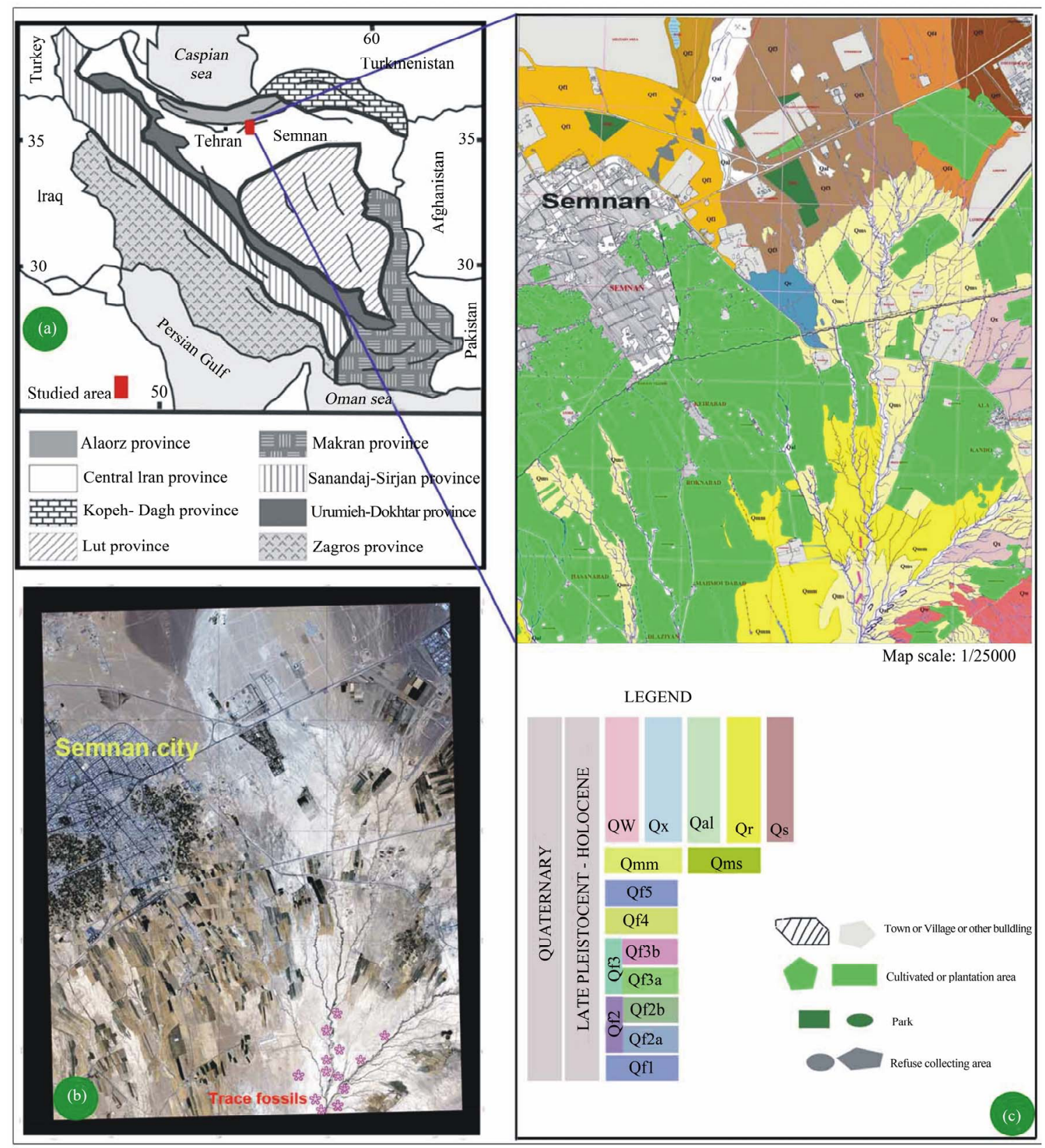

Figure 1. (a) Geological subdivision of Iran (redrawn after $[9,15])$. (b) Satellite image of Semnan. (c) Geological framework of Eastern Semnan.

towards southern part in a vast field with heavy slope and includes the city of Semnan. Semnan is situated at 1138 $\mathrm{m}$ above the sea level. This city is located on the route of Tehran to Khorasan Razavi province and has road and railway network with both of them. More precisely, the study area is located at about $14 \mathrm{~km}$ of the southeast of Semnan City and at Global Satellite Position, it coordi-

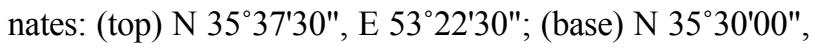
E $53^{\circ} 30^{\prime} 00^{\prime \prime}$. The section is mapped in the Semnan quadrangle map of the Geological Map of Iran [8] (Figures 1(b) and (c)).

\section{Geologic and Stratigraphic Framework}

Iran is structurally and palaeotectonically subdivided into several provinces [9] (Figure 1(a)):

- Kope-Dagh, in north-east of Iran, represented by the remnants of the Turan Plate, which was part of Laurussia;

- Central Iran, south of the suture zone, which is a mosaic of various Paleozoic blocks;

- The Alborz Mountains, in the North;

- Lut province;

- The Sanandaj-Sirjan belt, which extends from NW to 
South of Iran;

- The Zagros Mountains, in the west of the country, mainly represented by sediments of the Neotethys;

- Urumieh-Dokhtar;

- Makran.

Semnan province is situated in southern flank of the Alborz range and north of the great desert of Central Iran. Therefore, geologically it belongs to the Alborz and central Iran structural zones. The investigated area is located in the central Iran, where one of the most completed Quaternary successions in Iran is exposed.

In the East of Semnan City, Quaternary deposits occupy about $98 \%$ of the surface area, of which the Alluvial represents one of the most important geomorphological features in the area. The study of Quaternary deposits in the East of Semnan has attracted the interest of many earth scientists. Alluvial fans are common in many arid and semiarid regions such as the north and northeast of Semnan City. In these areas, alluvial-fan deposits provide an important record of Quaternary tectonics and climate changes. On a single fan, these deposits are often expressed geomorphically as multiple surfaces that can be distinguished from one another by their relief above the active channel, soil and varnish development, dip of the surface, and degree of dissection and degradation ([8]). Along the lower reaches of the East Semnan river, the Quaternary basin is thought to conceal a Tertiary basin (Figure 1(c)), which is called the East Semnan Basin, and has been filled with deposits by the paleo- and modern East Semnan River. Fluvial systems of semi-arid and arid areas of Semnan show a strong structural control on the drainage architecture and the landscape of the area, which has evolved due to neotectonism and palaeoenvironmental changes.

Qal: Recent alluvium, river bed, and channel deposits, gravels, sand and mud, unconsolidated.

Qs: Scree and slop washed, loose deposit.

Qw: Wind-blown sand (Eolian sand), Granoul, Coarse sand, silt and clay

Qx: Mixed deposits, eolian sand and mud Flat.

Qr: Reg (Desert pavement).

Qmm: Mosit Lime Mud (silt and clay), flood plain, salt plain.

Qms: Lime mud (very fine sand, silt and clay), salt flat and flood plain.

Fan unites Qf4: Moderately to poorly sorted, sand cobble and pebble gravel, composed of volcanic rock fragments (andesite, basalt and alterated argillitic).

Fan unites Qf5: The youngest fan surface, topographically lowest fan, composed of volcanic rock fragments (andesite, basalt and alterated argillite).

Fan unites Qf3b: This fan consists of sandy cobble and pebble gravel, composed of volcanic rock fragments, skarns and metasomatized rocks.
Fan unites Qf3a: This fan consists of massive clasticsupported sandy cobble gravel and pebble gravel, to poorly sorted.

Fan unites Qf2b: Poorly sorted sandy cobble and pebble gravel, composed of volcanic rock fragments, sandstone and siltstone.

Fan unites Qf2a: fan surface Qf2a is built beyond the farmer fan stage. An aerial photograph this surface is characterized by darker tones, dark gray to black, imposed of volcanic and sedimentary rock fragments.

Fan unites Qf1: The oldest segment has the highest topographic location, composed of sedimentary rock fragment.

\section{Material and Methods}

Sedimentological and ichnological data were gained through detailed observations and descriptions of the outcrops. Sedimentary textures, sedimentary structure, nature of bedding and bedding contacts, fossil content, and lateral variability were documented. Ichnological observations were concentrated on the identification of ichnogenera, the intensity of bioturbation, and the distribution of ichnofossils and ichnofossil assemblages [10].

The size of the ichnofossils, and their physical interrelationships (such as interpenetrating, intercalated, or isolated occurrences) were also noted.

This study of paleoichnology, follows the Treatise on Invertebrate Paleontology, [11], the morphological classification of Simpson [12], ethological classification of Seilacher [13], and facies classification of Seilacher [14].

\section{Ichnotaxonomy}

\subsection{Ichnogenuse Celliforma Brown, 1934}

Celliforma isp (Plate 1, Figures (a)-(d))

Diagnosis: Vasiform, globular or sub cyclindrical chambers or internal molds of chambers, distal or inner rounded, proximal or outer end eiyher truncated irregularly, or capped by a flat or conical closure, bearing Spiral or concentric groove on its inner surface. Walls polished and smooth so that internal mold is easily separated from rock matrix.

Description: Celliforma with brood cells $30 \mathrm{~mm}$ long, and $10 \mathrm{~mm}$ maximum diametr at a point about one-third the distance from the rounded end. cell lining thin(Less than $0.5 \mathrm{~mm}$ ). Cells arranged in flat lyning. preservation in the sediment is full relief.

Remarks: Although spiral caps have been found in the type species, this feature is not taken to be diagnostic of the genus. preservation of spiral caps is dependent on the failure of the young bee to emerge. therefore they are rare in fossil nests All the named species have internally polished cells. Only in Celliforma ficoides has the degree of clustering been established. 


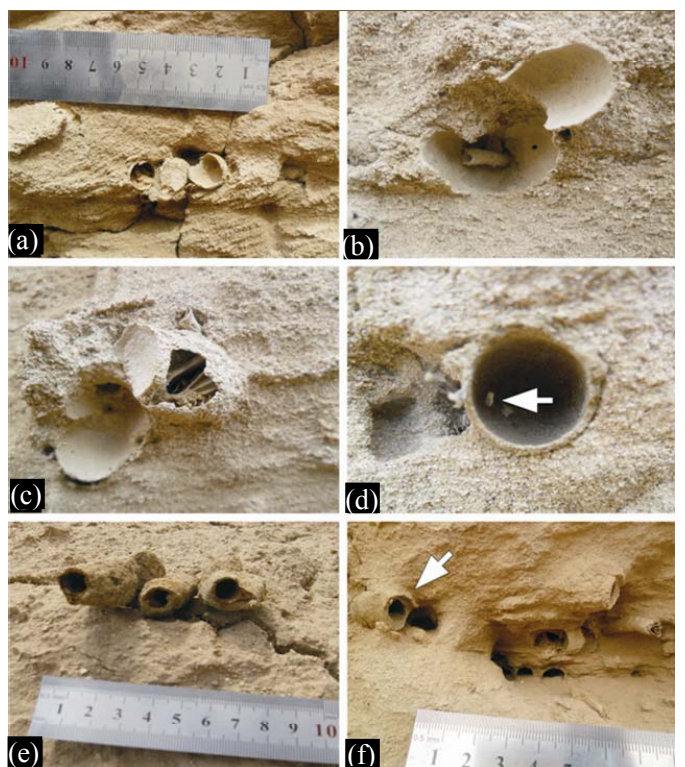

Plate 1. Figures (a)-(d): Ichnogenuse Celliforma Brown 1934. Figures e and f: Ichnogenuse Coprinisphaera Sauer 1955.

\subsection{Ichnogenus Coprinisphaera Sauer 1955}

Coprinisphaera isp ( Plate 2, Figures (e) and (f))

Diagnosis: Trace fossils consist of spherical, subs spherical, ovoid, or sub-ovoid chambers, generally isolated, rarely clustered. Chambers are surrounded by a discrete constructed wall, which may show a circular or ovoid hole. Some ichnogenera show empty or passively filled chambers, whereas in others active in fill is the norm.

Description: burrow diameter in this trace, 8 to $10 \mathrm{~cm}$ length and 2 to $2.5 \mathrm{~cm}$ diagonal. Internal lining is Smooth. In many case traces are cone shape. There is a hole in the end of Chambers. Preservation in the sediment is fullerlief.

Remarks: This ichnogenus is pending the ichnotaxonomic revision along with the closely related Coprinisphaera. Possible trace-makers are dung beetles (Scarabaeinae). The presence of a neck is the only feature that allows the separation of Fontanai from Coprinisphaera. The neck may be interpreted as the remains of a separate egg chamber that some dung-beetles construct over the provision chamber in their brood masses [16]. However, if the neck is interpreted as the remains of a former egg chamber, it would be possible to trace a continuous morphological series between both ichnogenera.

\subsection{Ichnogenus Palaeophycus Hall, 1847}

Ichnospecies Palaeophycus Tubularis (Hall, 1847) (Plate 1, Figures (a) and (b))

Diagnosis: Essentially cylindrical, predominantly subhorizontal, straight or slightly curved or slightly undulose, ornamented or smooth, branched or unbranched, lined burrows. Bifurcation is not systematic, nor does it result in swelling at the ramification points. The burrows do not systematically wind, meander or coil. Burrow fill typically massive, similar to host rock.

Description: Straight to slightly curved, subcylindrical to cylindrical, unornamented, smooth-walled burrows that are parallel to bedding or rarely slightly inclined. The diameters of each specimen are constant but vary between individuals from $10-19 \mathrm{~mm}$, while lengths vary between $25-70.5 \mathrm{~mm}$. The burrow fills are essentially similar to the surrounding host rock.

Remarks: Classification of Palaeophycus isp requires longitudinal views in order to determine whether striations or branching are present. Therefore, determination of Palaeophycus isp is precluded as the specimen is only preserved in vertical section. Palaeophycus herberti and $P$. tubularis differ from its other ichnospecies, namely $P$. striatus Hall, 1852, P. sulcatus [17] and P. alternatus, by being sculptured, distinctly lined and smooth-walled [18]. Palaeophycus herberti is distinguished by having a very thick lining with respect to its infill as opposed to $P$. tubularis that is thinly lined [18].

\subsection{Ichnogenus Planolites Nicholson, 1873}

\section{Planolithes Isp (Plate 2, Figure (c))}

Diagnosis: Unlined, rarely branched, straight or tortuous, smooth or ornamented, irregularly walled or annulate burrows, circular to elliptical in cross-section, predominantly horizontal, but bedding penetrative. The dimensions and configurations are variable and the fill is essentially massive.

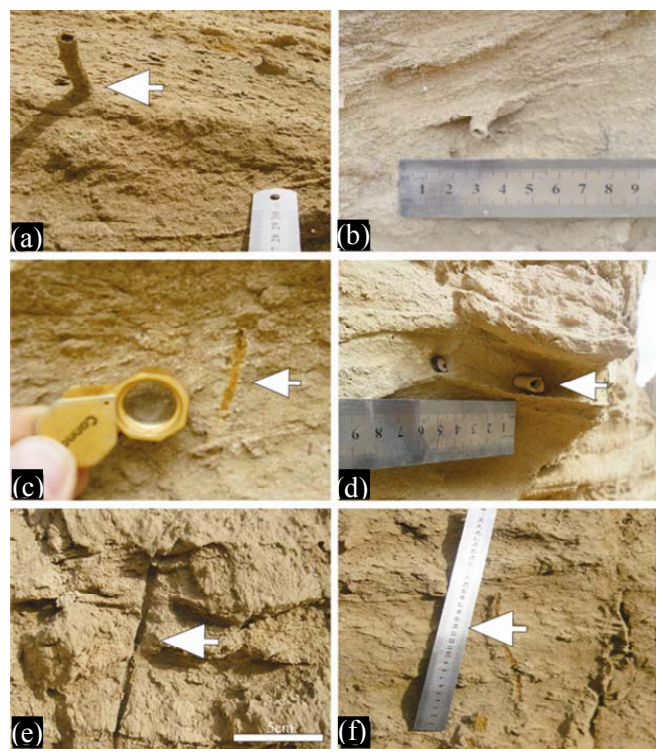

Plate 2. Figures (a) and (b): Ichnogenuse Palaeophycus Hall 1847. Figure (c): Ichnogenuse Planolites Nicholson 1873. Figure d: Ichnogenuse Tombownichnus n. igen. Figures (c)(e): Ichnogenuse Skolithos Haldemann 1840. 
Description: Horizontal, unlined, unbranched, straight to gently curving, unornamented cylindrical burrows. The diameters vary and range from $2-15 \mathrm{~mm}$. Burrow crowding and cross-cutting are commonplace. Burrow diameters are constant along exposed length and infill is typically massive and similar to the host rocks.

Remarks: The major difference between Planolites isp and Palaeophycus isp, its closest morphologically similar ichnogenus, is the distinct lining of the latter. Definitive determination of Planolites isp is precluded due the absence of longitudinal views, which is essential in determining ornamentation. Within the ichnospecies of Planolites, Planolites annularius Walcott, 1890 (characterized by transverse annulations), $P$. reinecki Ksiaz kiewicz, 1977 (characterized by both longitudenal striations and transverse annulations) and P. terraenovae Fillion \& Pickerill, 1990 (that exhibits continuous longitudinal striations) are ornamented, while $P$. montanus and $P$. beverleyensis are unornamented. Planolites montanus differs from $P$. beverleyensis by its smaller size and contorted morphology [18]. [19] suggested that these latter ichnospecies were synonymous with $P$. beverleyensis having priority.

\subsection{Ichnogenus Tombownichnus}

\section{Tombownichnus Plenus n. isp (Plate 2, Figure (d))}

Diagnosis: Circular to subcircular holes, or paraboloid external pits occurring in discrete (constructed) walls of chambers made of agglutinated soil material. A single hole, despite its size, is not diagnostic for this ichnogenus, which can be identified only when more than one hole is present. If the chamber shows a single large hole and one or more smaller ones, the former should be considered as part of the substrate (i.e. the constructed chamber). On the contrary, a single external pit is diagnostic for this ichnogenus.

Description: Slender, hair-like, unbranched, distinctly lined, slightly curved, cylindrical burrow that is oriented essentially vertical with respect to bedding. Burrow length is $8 \mathrm{~mm}$ and width is approximately $1 \mathrm{~mm}$. The lining contains an abundance of bioclastic fragments and is darker in colour than the host rock. The burrow-fill is similar to the host rock.

Remarks: Perforations were made by members of one of the three main groups of parasitoids of bees: Meloidae, Bombyliidae, or Mutillidae. Most parasitoids and cleptoparasites emerge and enter the cell through the entrance, either when it is still open, or by piercing the cap [20]. Incomplete perforations in fossil cells evidence that they were made from the outside inwards. This indicates that parasitoids, (e.g. velvet ants, Mutillidae), or predators (ground beetles, Carabidae), which enter cells by digging through the soil are the most probable trace makers [20].
In addition, some kind of scavenger, seeking the remains of provisions or larvae, should also be considered. Probably the completed holes, particularly those in lateral positions, may be attributed to the same producers.

\subsection{Ichnogenus Skolithos Haldemann 1840}

\section{Skolithos isp (Plate 2, Figures (e) and (f))}

Diagnosis: Straight tubes or pipes perpendicular to bedding plane, shafts parallel to eachother.Burrow wall distinct or indistinct, smooth to rough, some specimens annulated.

Description: Cylindrical to sub-cylindrical, vertical to slightly inclined burrows, unbranched, with variable diameter of the burrow, and the wall of the burrows are distinctly visible. It appears as a full relief shaft perpendicular to the bedding plane and diameter of burrow ranges from 8 to $16 \mathrm{~mm}$.

Remark: Skolithos occurs in shallow-marine environments [21], but also rarely in non-marine environments [22,23]. Marine Skolithos is mainly interpreted as a domichnion structure made by phoroids or annelids, while non-marine forms are related to insects or spiders as dwellings or shelters [24] or even to plants [23]. Archetypal Skolithos ichnofacies are related to relatively high energy environments, shallow water conditions, in near shore to marginal marine settings.

\section{Conclusions}

The lower part of Semnan Quaternary deposites (Figure 2) is started mainly by conglomerates that contain channel lag deposits. Continuance of this sequence is composed of Laminated to Cross bed sandeston, silt and mudston. Vertebrate footprints and Rhizoliths and mud crack are occasionally observed (Plate 3, Figures (a) and (b)). The Semnan Quaternary deposites in central Iran exhibits a moderately diverse trace fossil assemblage. It contains several taxa, such as: Celliforma isp, Coprinisphaera isp, Palaeophycus tubularis, planolithes isp, Tombownichnus plenus and Skolithos isp. these assemblages of trace fossils is related to Coprinisphaera ichnofacies. Vertebrate footprints and Rhizoliths imprints are the common members of Coprinisphaera ichnofacies. These trace fossils show subaerialconditions completely. It made by mammal walking in the muddy flood planes or muddy sheets. Completion of sequence in topsides, are related to a Paleosoils horizon. The Coprinisphaera Ichnofacies was erected by Genise et al. [6] to accommodate suites associated with more or less permanently suberially exposed continental settings. Recurrence in time is less clearly extensive, with assemblages spanning the Paleocene to Recent. Ethologically, the principal grouping is of nesting/breeding traces (calichnia; cf. [25], but the suites also clearly include other dwellings employed as 


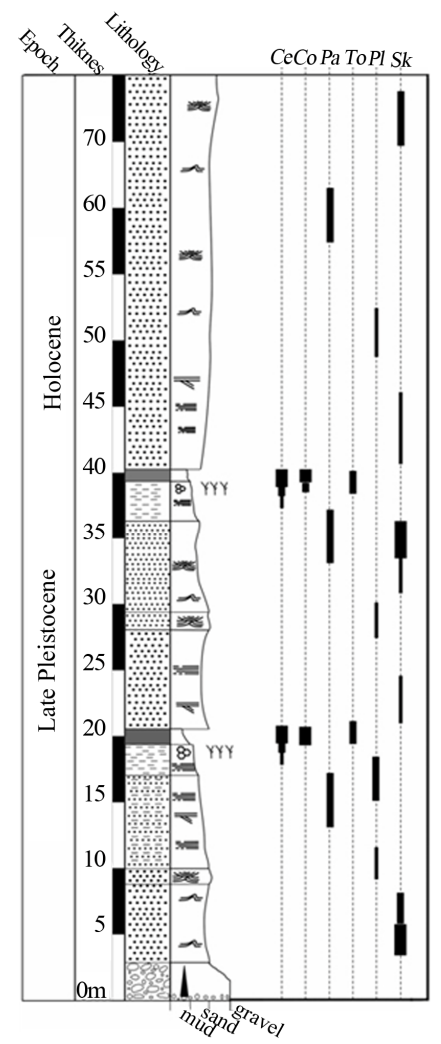

Figure 2. Lithostratigraphy column of semnans qaternary deposits and dispersal of continental trace fossils in these sediments.

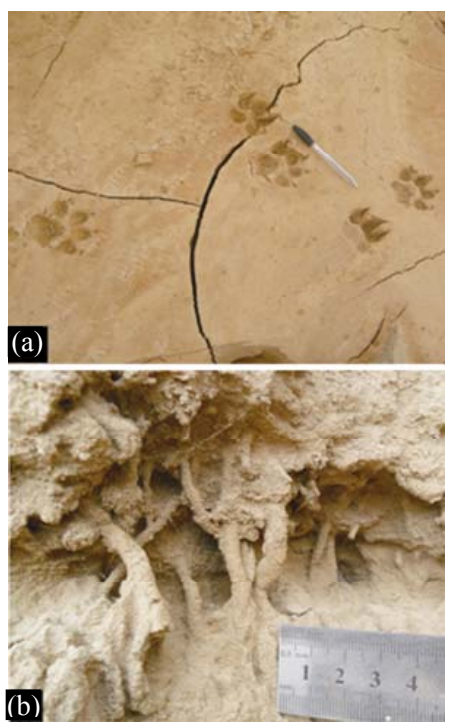

Plate 3. Figure (a): vertebrate footprints in Semnan quaternary sediment Figure (b): Rhizoliths in Semnan quarternary sediment.

refugia, aestivation, and ambush predation. Some mobile deposit feeding structures, larger (vertebrate) domiciles, and Rhizoliths are also included in some suites. Predominant trace-makers include bees, ants, wasps, beetles, termites and other unassigned insects. Termite nests are subordinate in abundance. The ichnofacies namesake is for one of the most common structures; the nest structure of dung beetles.

Suites are prone to complex tiering patterns, particularly in mature soils, reflecting the variable depths of emplacement of hymenopterous, termite, and dung beetle nests [6]. Suites show moderate to relatively high diversity, and generally high abundances of traces, particularly in mature paleosoils. Settings characteristic of the Coprinisphaera Ichnofacies correspond to paleosols developed in paleoecosystems of herbaceous communities; this may effectively limit the ichnofacies to units ranging from Late Cretaceous to the Recent Climatically, settings range from arid and cold steppes (dominated by hymenopterous nests) to humid and hot subtropical savannas (dominated by termite nests).

Paleosol settings occupy alluvial plains, desiccated floodplains, crevasse splays, levees and abandoned point bars, and vegetated eolian environments (Figure 3) [6]. These settings are strongly controlled by microclimates (e.g., temperature, radiation, humidity, wind speed near the ground) associated with vegetation, topography, and overall climatic conditions. Also this ichnofacies occur in looseground, firmground, and stiff ground [27] (Figure 4).

\section{Result}

Biogenic structures registered in sediments from the semnan area have been described in detail and characterized taxonomically at the ichnospecies level for the first time. Ichnological analysis of the semnan Quarternary deposits reveals a relatively abundant and moderately diverse trace fossil assemblage. It contains several taxa, such as Celliforma, Coprinisphaera, Palaeophycus, Planolites, Tombownichnus and Skolithos. Existence this ichnoassemblage together Vertebrate footprints and Rhizoliths, represents the record of classical Coprinisphaera ichnofacies in this deposits. Based on the semnan Quaternary sediments are deposits in floodplains condition.

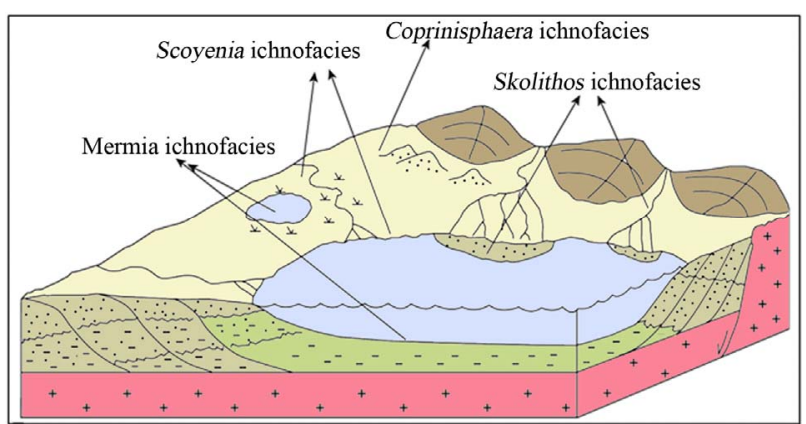

Figure 3. Ichnofacies model for Coprinisphaera ichnofacies (after of [26]). 


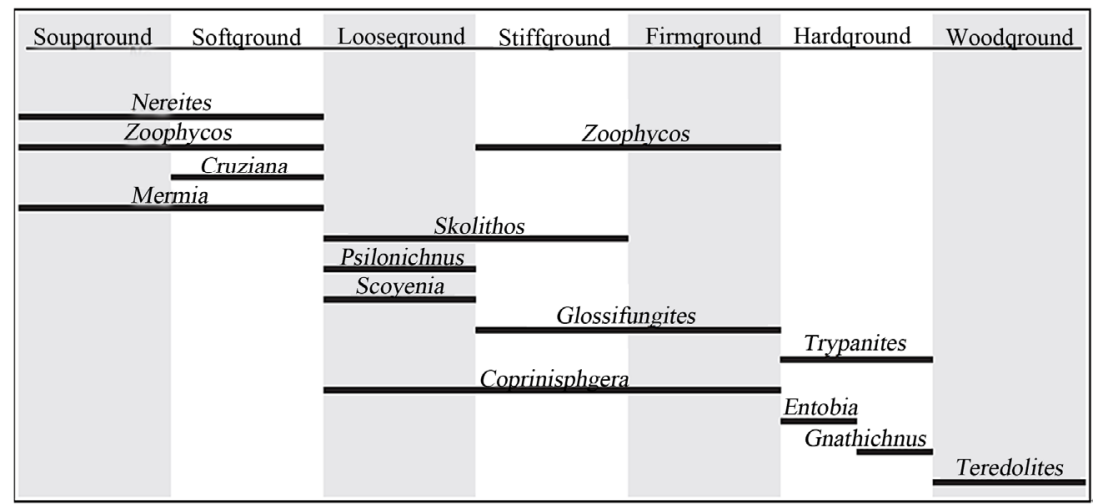

Figure 4. Relationship of substrate type and Coprinisphaera ichnofacies.( After of [27]).

\section{Acknowledgements}

Authors would like to be thankful to Geological Survey of Iran (GSI) for logistic support during field work and deeply thank geology branch of Islamic Azad University of Urumieh for support of the research.

\section{REFERENCES}

[1] R. Bromley, L. A. Buatois, M. G. Mángano, J. Genise and R. Melchor, "Sediment-Organism Interactions: A Multifaceted Ichnology," SEPM Special Publication, No. 88, 2007, pp. 88-393.

[2] R. G. Bromley, "Trace Fossils: Biology and Taphonomy," Unwin Hyman, London, 1990.

[3] M. L. Droser and D. J. Bottjer, "Trace Fossils and Ichnofabric in Leg 119 Cores," In: J. Barron, B. Larsen, et al., Eds., Proceedings of the Ocean Drilling Program, Scientific Results, Ocean Drilling Program, College Station, 1991, pp. 635-641.

[4] S. G. Pemberton, J. A. MacEachern and R. W. Frey, "Trace Fossil Facie Models: Environmental and Allostratigraphic Significance," In R. G. Walker and N. P. James, Eds., Facies Models: Response to Sea Level Change, 1992, pp. 47-72.

[5] J. A. MacEachern, S. G. Pemberton, M. K. Gingras and K. L. Bann, "The Ichnofacies Concept: A Fifty-Year Retrospective," In: W. Miller III, Ed., Trace Fossils: Concepts, Problems, Prospects, Elsevier, Amsterdam, 2007, pp. 5075.

[6] J. F. Genise, "The Ichnofamily Celliformidae for Celliforma and Allied Ichnogenera," Ichnos, Vol. 7, No. 4, 2000, pp. 267-284. doi:10.1080/10420940009380166

[7] S. T. Hasiotis, "Continental Trace Fossils: Society of Economic Paleontologists and Mineralogists," Short Course Notes, No. 51, 2002, p. 132.

[8] M. H. Nabavi, "Semnan Quadrangle Map 1:100,000," Geological Survey of Iran, Geological Quadrangle, 1987.

[9] M. Berberian and G. C. P. King, "Towards a Paleogeography and Tectonic Evolution of Iran," Canadian Journal of Earth Sciences, Vol. 18, No. 2, 1981, pp. 210-265. doi:10.1139/e81-019

[10] S. G. Pemberton and R. W. Frey, "Quantitative Methods in Ichnology: Spatial Distribution among Populations," Lethaia, Vol. 17, No. 1, 1984, pp. 33-49. doi:10.1111/j.1502-3931.1984.tb00663.x

[11] W. Häntzschel, "Trace Fossils and Problematica," In: R. C. Moore, Ed., Treatise on Invertebrate Paleontology, Part W. Geological Society of America, New York and University of Kansas Press, Lawrence, 1962, p. W177.

[12] S. Simpson, "Classification of Trace Fossils," In: R. W. Frey, Ed., The Study of Trace Fossils, Springer Verlag, Berlin, 1975, pp. 39-54. doi:10.1007/978-3-642-65923-2 3

[13] A. Seilacher, "Biogenic Sedimentary Structures," In: J. Imbrie and N. D. Newell, Eds., Approaches to Paleoecology, John Willey and Sons, New York, 1964, pp. 246316.

[14] A. Seilacher, "Bathymetry of Trace Fossils," Marine Geology, Vol. 5, No. 5-6, 1967, pp. 413-428. doi:10.1016/0025-3227(67)90051-5

[15] H. Vaziri-Moghaddam, M. Kimiagari and A. Taheri, "Depositional Environment and Sequence Stratigraphy of the Oligo-Miocene Asmari Formation in the SW Iran," Facies, Vol. 52, No. 1, 2006, pp. 41-51. doi:10.1007/s10347-005-0018-0

[16] G. Halffter and E. G. Matthews, "The Natural History of Dung Beetles of the Subfamily Scarabaeinae (Coleoptera: Scarabaeidae)," Folia Entomológica Mexicana, Vol. 12, No. 14, 1966, pp. 1-312.

[17] S. A. Miller and C. B. Dyer, "Contributions to Paleontology," Cincinnati Society of Natural History, Vol. 1, No. 1, 1878, pp. 24-39.

[18] S. G. Pemberton and R. W. Frey, "Trace Fossil Nomenclature and the Planolites-Palaeophycus Dilemma," Journal of Paleontology, Vol. 56, 1982, pp. 56843-56881.

[19] D. G. Keighley and R. K. Pickerill, "Systematic Ichnology of the Mabou and Cumberland Groups (Carboniferous) of Western Cape Breton Island, Eastern Canada, 1: Burrows, Pits, Trails and Coprolites," Atlantic Geology, Vol. 33, No. 3, 1997, pp. 181-215.

[20] H. E. Evans and M. J. W. Eberhard, "The Wasps," University of Michigan Press, Ann Arbor, 1970.

[21] D. Fillion and R. K. Pickerill, "Ichnology of the Upper Cambrian? To Lower Ordovician Bell Island and Wabana 
groups of Eastern Newfoundland, Canada," Palaeontographica Canadiana, Vol. 7, 1990, pp. 1-83.

[22] R. G. Bromley and U. Asgaard, "Triassic Freshwater Ichnocoenoses from Carlsberg Fjord, East Greenland," Palaeogeography, Palaeoclimatology, Palaeoecology, Vol. 28, 1979, pp. 39-80. doi:10.1016/0031-0182(79)90112-3

[23] R. Gregory, D. Ohlson and J. Arvai, "Deconstructing Adaptive Management: Criteria for Applications to Environmental Management," Ecological Applications, Vol. 16, No. 6, 2006, pp. 2411-2425.

doi:10.1890/1051-0761(2006)016[2411:DAMCFA]2.0.C $\mathrm{O} ; 2$

[24] M. Schlirf and A. Uchman, "Revision of the Ichnogenus Sabellarifex Richter, 1921 and Its Relationship to Skolithos Haldeman, 1840 and Polykladichnus Fürsich, 1981," Journal of Systematic Palaeontology, Vol. 3, No. 2, 2005, pp. 115-131. doi:10.1017/S1477201905001550

[25] J. F. Genise and T. M. Bown, "Uruguay Roselli and Rosellichnusn. Ichnogen. Two Ichnogenera for Cluster of Fossil Beecells," Ichnos, Vol. 4, No. 3, 1996, pp. 199-217. doi:10.1080/10420949609380127

[26] L. Buatois and M. G. Mangano, "Animal-Substrate Interactions in Freshwater Environments: Applications of Ichnology in Facies and Sequence Stratigraphic Analysis of Fluvio-Lacustrine Successions," In: D. McIlroy, Ed., The Application of Ichnology to Paleoenvironmental and Stratigraphic Analysis, Geological Society, London, 2004, pp. 311-333.

[27] W. Miller, "Trace Fossils-Concepts, Problems, and Prospects," Elsevier Press, Amsterdam, 2007. 